\title{
Migratory connectivity and conservation of the Amur Falcon Falco amurensis: a stable isotope perspective
}

\author{
CRAIG T. SYMES and STEPHAN WOODBORNE
}

\section{Summary}

Stable isotopes $\left(\delta \mathrm{D}, \delta^{13} \mathrm{C}, \delta^{15} \mathrm{~N}\right)$ were measured in adult and juvenile Amur Falcon Falco amurensis feathers to understand the migratory connectivity of this species. Using the OIPC (Online Isotopes in Precipitation Calculator) and a calibration curve for American Kestrels Falco sparverius we predicted the breeding range of South African Amur Falcons in the Palaearctic. $\delta \mathrm{D}$ values for juvenile feathers (mean $\pm \mathrm{SE}=-58.1 \pm 2.5 \%$, range -83.9 to $-25.7 \%$ ) and predicted Palaearctic annual precipitation values indicated that juvenile Amur Falcons in South Africa originated from across their entire Palaearctic range. This rejects the leapfrog migration hypothesis and suggests the widespread movement of birds south, with a funnelling effect into the subregion where they become concentrated over a narrower distribution range. Adult $\delta \mathrm{D}_{\mathrm{f}}$ values were more depleted $(-37.4 \pm 1.8 \%$, range $=-71.3$ to $-9.3 \%$ ) than predicted annual precipitation values for sites where feathers moulted in South Africa $(-20.2 \pm 0.9 \%)$ but there was no correlation between $\delta \mathrm{D}_{\mathrm{p}}$ and $\delta \mathrm{D}_{\mathrm{f}}$. This, together with significant variation of $\delta^{13} \mathrm{C}$ among sites and annual fluctuations in roost sizes, suggests that roost site fidelity is low in the overwintering range. Populations not confined to breeding sites in South Africa are able to move widely across the subregion, feeding on a broad range of arthropods that become seasonally abundant during the austral summer. Total population estimates for South Africa are significantly lower than global estimates so a significant proportion of the population may not overwinter in South Africa or global populations are significantly lower than estimated. In South Africa, roosts that number hundreds to thousands of individuals are often in large exotic trees, e.g. Eucalyptus sp. They are often tolerant of disturbance at roosts which may be of little concern for their conservation. Habitat changes in the overwintering range in South Africa though, particularly due to agriculture, afforestation and strip mining, may affect global population numbers. There is also concern over the persecution of birds along their migratory route.

\section{Introduction}

The migration of raptors constitutes one of the most spectacular movements of predators on earth (Bildstein and Zalles 2005). Because of their trophic status, raptors act as useful flagship species for conservation (Bildstein et al. 200o). The greatest threat to migratory raptors is habitat loss, so understanding their migration patterns is important for effective conservation strategies (Alerstam 1990, Bildstein et al. 2000). Little is known about the migratory movements of many raptor species, particularly those moving between Asia and Africa (McClure 1998) despite recent advances in satellite telemetry that have contributed to understanding movements of some species (Meyburg et al. 1995, Kjellen et al. 1997, Meyburg et al. 2001, Trierweiler et al. 2007). The application of the technique is limited by the lower limit of transmitter size, currently $\sim 5 \mathrm{~g}$ (Strandberg et al. 2009) which prevents similar studies on smaller migrants. The lightest 
species tracked to date has recently decreased from the Eurasian Hobby Falco subbuteo Linnaeus 1758 (mass $=$ c. 230 g; Strandberg et al. 2009) to the Red-footed Falcon F. vespertinus Linnaeus 1766 (mass $=$ c. $135 \mathrm{~g}$ ).

It is important in the conservation and long-term survival of migratory raptors, particularly in the context of global climatic changes and rapid habitat modification due to human activity, to determine their migratory origins. En route migratory stopover points may be critical for many species (Bildstein et al. 2000), but equally important are the final "over-wintering" destinations where the build-up of resources for the coming breeding season may be crucial (Sanderson et al. 2006). In the southern African subregion there is a funnelling effect of migrants from an extensive longitudinal range in the northern hemisphere (Newton 1995, Bildstein and Zalles 2005, Dingle 2008). This has implications for the conservation of many migrant species that "over-winter" in South Africa during the austral summer because the population is concentrated over a smaller area in their non-breeding African range.

Of particular concern is the Amur Falcon Falco amurensis Radde 1863, a small (male, 137.6 g, $n=18$, female, $159.5 \mathrm{~g}, n=26$; Schäfer 2003) insectivorous raptor that undergoes a one-way migration of $\sim 13,000 \mathrm{~km}$ (Ferguson-Lees and Christie 2001, Mendelsohn 1997, Jenkins 2005). This includes the longest regular over-water passage of any raptor, flying over the Indian Ocean between south-western India and East Africa, a distance of c. 4,000 km (Cade 1982, Ali and Ripley 1987, Orta 1994, Mendelsohn 1997, Bildstein et al. 2000, Birdlife International 2008). It breeds over a wide range in Mongolia, Siberia and northern China, although little has been documented on its distribution in the Palaearctic (Cheng 1987, Mendelsohn 1997, Ferguson-Lees and Christie 2001, Bildstein and Zalles 2005, Global Raptor Information Network 2008). Birds arrive in southern Africa during November to early December and roost in colonies that number thousands of individuals (Benson 1951, Cade 1982, Tarboton and Allan 1984). For a number of months they are a common sight on the eastern Highveld, before departing north again during April to May (Mendelsohn 1997, Jenkins 2005).

Stable hydrogen isotopes have been used to determine migratory connectivity of numerous species in the Americas and Europe (e.g. Chamberlain et al. 1997, Hobson 2008, Chamberlain et al. 2000, Meehan et al. 2001, Hobson et al. 2004a,b). On a global scale, the distribution of $\delta \mathrm{D}_{\mathrm{p}}$ is relatively predictable, with a general depletion (more negative $\delta$ values) in $\delta \mathrm{D}_{\mathrm{p}}$ with an increase in latitude (Bowen and Revenaugh 2003). The assimilation of this water during feather growth, at different latitudes, can then be used to indicate the origins of birds (Hobson and Wassenaar 2008). On a broad scale, the relationship between the isotope signature of precipitation $\left(\delta \mathrm{D}_{\mathrm{p}}\right)$ and that of feathers $\left(\delta \mathrm{D}_{\mathrm{f}}\right)$ is usually linear, with $\delta \mathrm{D}_{\mathrm{f}}$ values being $20-50 \%$ o depleted (more negative) than that of $\delta \mathrm{D}_{\mathrm{p}}$ values (Meehan et al. 2001, Wassenaar and Hobson 2001, Wassenaar and Hobson 2003, Hobson and Wassenaar 2008). This understanding of $\delta \mathrm{D}$ patterns has been particularly useful in determining the movement patterns and migratory origins of long distance migrants across the globe (e.g. Hobson and Wassenaar 1997, Hobson and Wassenaar 2008). Within Africa the hydrogen isotope gradient on either side of the equator is low, so movements of birds within the continent are more difficult to study using stable isotopes (but see Yohannes et al. 2005, Yohannes et al. 2007, Wakelin et al. in press).

Distinct isotope fractionation processes occur during the $\mathrm{C}_{3}$ and $\mathrm{C}_{4}$ photosynthetic pathways, resulting in unique isotope signatures for each vegetation type that animals feed on; $\mathrm{C}_{3}$ plants are typically more depleted in ${ }^{13} \mathrm{C}$ relative to $\mathrm{C}_{4}$ and CAM plants (Park and Epstein 1960, Park and Epstein 1961, Smith and Epstein 1971, Vogel et al. 1978, Ehleringer 1991, Dawson et al. 2002). Also, the distributions of $\mathrm{C}_{3}$ and $\mathrm{C}_{4}$ plants are associated with broad-scale global patterns of plant distribution (Stowe and Teeri 1978). Studies of animal tissues that reflect diet can therefore be good indicators for interpreting the use of different resources $\left(\mathrm{C}_{3}\right.$ or $\left.\mathrm{C}_{4}\right)$ on temporal and spatial scales (e.g. Cerling et al. 2006). On the other hand, nitrogen isotopes are a useful tool in understanding trophic ecology because each step in a food chain is usually associated with an isotopic enrichment of $3-5 \%$ from diet to animal tissue (Peterson and Fry 1987, Mizutani et al. 1992, Kelly 2000, Post 2002). Nitrogen and carbon are therefore useful 
elements in identifying carbon sources and delineating trophic levels of organisms (Minagawa and Wada 1984, Peterson and Fry 1987, Hobson and Wassenaar 1999).

Accordingly, stable isotope data from feathers of South African Amur Falcons were analysed to address specific questions concerning migratory connectivity and local movements in the overwintering range of this species. Because Amur Falcons breed in the northern hemisphere we expected stable hydrogen isotopes in the feathers of juveniles to reflect their origins. Adults, on the other hand, undergo a complete flight feather moult in southern Africa (Northern Flagship Institution unpubl. data), so isotopes in feathers were expected to reflect the area in which the feathers grew. Some feathers (i.e. $\mathrm{P}_{4}-6$ and $\mathrm{S}_{5}-7$ ) appear to moult in the Palaearctic (Schäfer 2003) and are not re-moulted in southern Africa. To complement analyses using hydrogen isotopes, we used stable carbon and nitrogen isotopes that provide further information on diet, to provide additional support for answering questions relating to movements of Amur Falcons. More specifically, we attempted to answer the following questions; I) Can we determine the breeding origins of birds in the Palaearctic? 2) Do Amur Falcons display a leap-frog migration pattern, i.e. northernmost breeding birds overwinter furthest south? 3) Do members of roosting flocks originate from similar regions in the northern hemisphere? 4) Do populations exhibit roost fidelity in the South African subregion?

\section{Materials and Methods}

\section{Feather collection}

Specimens of individual adult male and female and juvenile male and female Amur Falcons that were killed during a thunderstorm on 25 December 2004 at a roost in Ventersdorp were collected for analysis (Bernitz 2006). These specimens, housed in the Transvaal Museum, Pretoria, were surgically sexed and used as a feather identification reference for additional samples collected from beneath roosts throughout South Africa during December 2008-March 2009. The museum specimens were also sampled. Details of sites and number of samples collected at each site are given in Table 1 .

\section{Sample preparation and isotopes analysis}

Feathers were washed in distilled water to remove faecal matter, followed by cleansing in a 2:1 chloroform:methanol solution to remove surface oils and contaminants (Hobson et al. 2003, 2004a). ${ }^{13} \mathrm{C} /{ }^{12} \mathrm{C}$ isotope ratios are given relative to Vienna Pee Dee Belemnite (VPDB), ${ }^{15} \mathrm{~N} /{ }^{14} \mathrm{~N}$ ratios relative to Air and ${ }^{2} \mathrm{H} /{ }^{1} \mathrm{H}$ ratios relative to Vienna Standard Mean Ocean water (VSMOW), with values expressed in $\delta$ notation in parts per thousand (per mille, \%o).

Table 1. Amur Falcon feather collection sites in South Africa (ordered from northernmost to southernmost) and number of samples collected at each site.

\begin{tabular}{lllllll}
\hline Location & Grid reference & $\begin{array}{l}\text { Altitude } \\
\text { m a.s.l. }\end{array}$ & $\begin{array}{l}\text { Adult } \\
\text { female }\end{array}$ & $\begin{array}{l}\text { Adult } \\
\text { male }\end{array}$ & Juvenile & TOTAL \\
\hline Naboomspruit & $24^{\circ} 25^{\prime} \mathrm{OI}^{\prime} \mathrm{S} 28^{\circ} 55^{\prime} \mathrm{OI}^{\prime} \mathrm{E}$ & 1,098 & 5 & 5 & 4 & 14 \\
Middelburg & $25^{\circ} 4^{\prime} 3 \mathrm{O}^{\prime} \mathrm{S} 29^{\circ} 27^{\prime} 57^{\prime} \mathrm{E}$ & 1,490 & 5 & 5 & 7 & 17 \\
Ventersdorp & $26^{\circ} 19^{\prime} 36^{\prime} \mathrm{S} 26^{\circ} 49^{\prime} 18^{\prime} \mathrm{E}$ & 1,349 & 5 & 5 & $10^{*}$ & 20 \\
Heidelberg & $26^{\circ} 30^{\prime} 15^{\prime} \mathrm{S} 28^{\circ} 21^{\prime} 26^{\prime} \mathrm{E}$ & 1,482 & 8 & 5 & 1 & 14 \\
Newcastle & $27^{\circ} 46^{\prime} 14^{\prime} \mathrm{S} 29^{\circ} 56^{\prime} 27^{\prime} \mathrm{E}$ & 1,185 & 5 & 5 & 11 & 21 \\
Graaff-Reinet & $32^{\circ} 15^{\prime} 41^{\prime} \mathrm{S} 24^{\circ} 32^{\prime} 14^{\prime} \mathrm{E}$ & 719 & 0 & 0 & 3 & 3 \\
Pearston & $32^{\circ} 34^{\prime} 59^{\prime} \mathrm{S} 25^{\circ} 8^{\prime} 12^{\prime} \mathrm{E}$ & 704 & 1 & 0 & 0 & 1 \\
& & & 29 & 25 & 36 & 90 \\
\hline
\end{tabular}

${ }^{*}$ Five male and five female specimens. Details of Transvaal Museum specimens are given in Appendix 1 . 
For $\delta^{13} \mathrm{C}$ and $\delta^{15} \mathrm{~N}$ analyses, representative samples (0.15-0.30 mg) were weighed in tin cups (pre-cleaned in toluene) and combusted at $1,020^{\circ} \mathrm{C}$ in an Elemental Analyser (Flash EA, 1112 Series, Thermo Electron Corporation, Bremen, Germany). The ${ }^{13} \mathrm{C} /{ }^{12} \mathrm{C}$ and ${ }^{15} \mathrm{~N} /{ }^{14} \mathrm{~N}$ isotope ratios were then determined using a Thermo Delta V Plus continuous-flow isotope ratio mass spectrometer (CFIRMS) (Thermo Electron Corporation) plumbed in-line with the elemental analyser via a Conflo IV gas controller (Thermo Fisher Scientific, Bremen, Germany). Two aliquots of a laboratory standard (homogenised dried chicken blood; mean $\delta^{13} \mathrm{C} \pm \mathrm{SD}=-17.87 \pm$ $0.15 \%, n=331$ ) were used for every six to eight unknowns in sequence. In order to correct for equipment drift, duplicates were run for each sample. The laboratory standard was standardised against C652 ANU sucrose, 1577b bovine liver (National Institute of Standards and Technology) and SRM 1547 peach leaves (NIST).

In order to discount the exchangeable hydrogen fractionation we used a comparative equilibration approach where samples are equilibrated with the same ambient water vapour as working standards with known non-exchangeable $\delta \mathrm{D}$ values (Wassenaar and Hobson 2003). Feather samples (0.15-0.30 mg) and keratin working standards (BWB-II $=108 \pm 4 \%{ }^{\prime}$ CFS $=138$ $\pm 5 \%$, CHS $=187 \pm 2 \%$; Wassenaar and Hobson 2003) were weighed into silver cups and stored for $72 \mathrm{hr}$ at room temperature prior to analysis. The ${ }^{2} \mathrm{H} /{ }^{1} \mathrm{H}$ ratios were measured using a high temperature TC/EA elemental analyzer (Thermo Fisher Scientific, Bremen, Germany) with pyrolysis at $1,450^{\circ} \mathrm{C}$ that was coupled to the CFIRMS. A linear regression model fitted between measured $v s$ actual $\delta \mathrm{D}$ values for the three keratin working standards was used to correct the $\delta \mathrm{D}$ values of the feather samples (Wassenaar and Hobson 2003).

\section{Data analyses}

All mean values are presented $\pm \mathrm{SE}$, unless otherwise stated. Where data were normally distributed we conducted t-tests and where data were not normally distributed we conducted a non-parametric Mann-Whitney U-test, between adult and juveniles, and males and females. For comparisons between sites we used an ANOVA where data were normally distributed and a Kruskal-Wallis test where data were not normally distributed. Comparisons of $\delta \mathrm{D}$ in adult feathers with the predicted $\delta \mathrm{D}$ values of precipitation for the site where the feathers were collected (in South Africa) were made using a simple bivariate regression model. We calculated the $\delta \mathrm{D}(\%$, VSMOW) value of precipitation for each site where feathers were collected in South Africa using The Online Isotopes in Precipitation Calculator (OIPC) (Bowen et al. 2005, Bowen 2009). To predict the origins of juveniles we calculated the $\delta \mathrm{D}$ values for precipitation (where the birds originated) by using a calibration curve derived for American Kestrels Falco sparverius (Hobson et al. 2009). This calibration curve was derived from known-source $F$. sparverius feathers (from Lott and Smith 2006), and predicted growing-season $\delta \mathrm{D}$ in precipitation (from Bowen et al. 2005). We cannot be sure of the proportion of prior precipitation that contributes to tail feather growth of juveniles. This is because a broad range of integration from the environment, representing a wider temporal period than simply the integration of $\mathrm{D}$ during the month of feather growth, is likely. We therefore used an annual mean $\delta \mathrm{D}$ value of precipitation throughout the breeding range to predict the $\mathrm{D}$ in precipitation that contributed to feather growth (Hobson et al. 2009). In the northern Palaearctic the mean growing season average of precipitation $\delta \mathrm{D}$ values, as an estimate of mean hydrogen isotope input to the food webs, is typically used and is usually defined as those months where temperature is $>{ }^{\circ} \mathrm{C}$. In temperate regions this may also include snow. However, until there is a good $\delta \mathrm{D}$ feather map for the Palaearctic this interpretation will remain an issue. Tail feathers of juveniles grow mostly during June (Schäfer 2002). We therefore expected the diet of Amur Falcons in their breeding range, which includes a wide range of invertebrate and small vertebrate prey (e.g. birds, rodents, amphibians; Schäfer 2003); to represent precipitation many months prior to feather growth. The predicted $\delta \mathrm{D}$ values of precipitation that indicated the origins of juvenile feathers were then overlaid with the distribution range of Amur Falcons in the Palaearctic to indicate the likely 
origins of juveniles that we sampled in South Africa (Ferguson-Lees and Christie 2001, S. Gombobaatar unpubl. data). We also overlaid this distribution with precipitation $\delta \mathrm{D}$ values (that indicated the origins of juvenile feathers) for the month (June) when juvenile feathers grew, but do not present the data.

\section{Results}

Shapiro-Wilk's test for normality indicated that data were normally distributed for $\delta \mathrm{D}(W=$ $0.9859, P=0.46)$ but not normally distributed for $\delta^{15} \mathrm{~N}(W=0.9673, P=0.02)$ and $\delta^{13} \mathrm{C}(W=$ $0.9267, P<0.01$ ).

The $\delta \mathrm{D}$ values for juveniles were significantly depleted compared to adults (adults $=-37.4 \pm$ $1.8 \%$, range $=-71.3$ to $-9.3 \%$ o juveniles $=-58.1 \pm 2.5 \%$, range $=-83.9$ to $-25.7 \%$ o $t=$ $-6.87, \mathrm{df}=86, P<0.001$; Figure 1 ). There was no significant difference among sites for juveniles (ANOVA, $F_{5,29}=0.984, P=0.44$ ) or adults (ANOVA, $F_{4,48}=0.930, P=0.45$ ). The $\delta \mathrm{D}$ values for adult males and females were similar (male $=-37.2 \pm 2.5 \%$, female $=-37.6 \pm$ $2.6 \%, t=0.087, \mathrm{df}=51, P=0.93)$. Also, $\delta \mathrm{D}$ values did not differ among sites for males (ANOVA, $F_{4,20}=0.280, P=0.887$ ) or females (ANOVA, $F_{4,23}=1.174, P=0.348$ ) (Figure 1 ).

Values for $\delta^{13} \mathrm{C}$ between adults and juveniles were not significantly different, (Mann-Whitney $U=807.0, P=0.174$, adults $-18.6 \pm 0.4 \%$, juveniles $=-19.3 \pm 0.5 \%$ oo . For adults there was a significant difference among sites (Kruskal-Wallis test: $H_{5,54}=15.33, P=0.009$ ) with a posthoc test determining Ventersdorp adults $\left(\delta^{13} \mathrm{C}=-15.5 \pm 0.7 \%\right.$ ) to be more enriched than Newcastle adults $\left(\delta^{13} \mathrm{C}=-19.6 \pm 1.1 \%\right.$ o $)(P=0.03)$. For juveniles, although there was no significant difference among sites (Kruskal-Wallis test: $H_{4,34}=7.63, P=0.11$ ), although post-hoc tests revealed Ventersdorp $(-17.9 \pm 0.8 \%$ ) to be more enriched than Graaff-Reinet $(-21.8 \pm 0.4 \%)$, Middelburg $(-20.0 \pm 0.9 \%)$ and Naboomspruit $(-17.5 \pm 2.8 \%)$, and Newcastle $(-20.3 \pm 0.7 \%$ o $)$ more enriched than Graaff-Reinet $(P<0.05)$ (Figure 1 ).

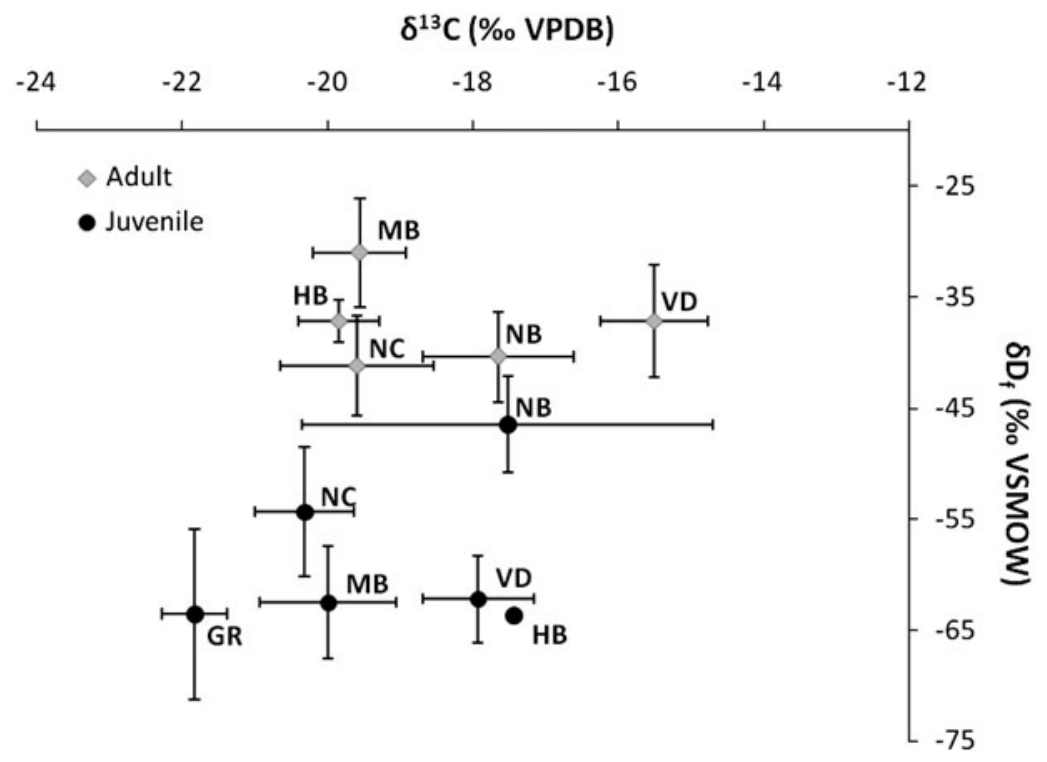

Figure 1. Mean $\delta^{13} \mathrm{C}(\mathrm{VPDB})$ and $\delta \mathrm{D}(\mathrm{VSMOW})(\% \pm \mathrm{SE})$ values of feathers for adult and juvenile Amur Falcons from different roost sites in South Africa. See Table 1 for details of sites and sample sizes. $\mathrm{MB}=$ Middelburg, $\mathrm{GR}=$ Graaff-Reinet, $\mathrm{NB}=$ Naboomspruit, $\mathrm{NC}=$ Newcastle, $\mathrm{HB}=$ Heidelberg, $\mathrm{VD}=$ Ventersdorp. 
Values for $\delta^{15} \mathrm{~N}$ were similar between adults and juveniles (Mann-Whitney $U=911.0, P=$ 0.61 , adults $=7.6 \pm 0.3 \%$, juveniles $=7.3 \pm 0.4 \%$ o. For adults and juveniles there was no difference among sites (Kruskal-Wallis test: $H_{5,54}=4.33, P=0.50$ and $H_{5,36}=5.33, P=0.38$, respectively; Table 2).

Using a global model of $\delta \mathrm{D}$ in precipitation we calculated predicted annual values of $\delta \mathrm{D}$ $(-20.2 \pm 0.9 \%, n=5$ sites $)$, for each site in South Africa where we collected adult feathers (Bowen et al. 2005, Bowen 2009). Adult $\delta \mathrm{D}_{\mathrm{f}}$ values ranged from $-71.3 \%$ to $-9.3 \%$ (mean $=$ $-37.4 \pm 1.8 \%$ on and mean site values were all more depleted $(3.0-18.4 \%$ ) than predicted annual precipitation $\left(\delta \mathrm{D}_{\mathrm{p}}\right)$ values. The $\delta \mathrm{D}_{\mathrm{f}}$ values of adult feathers from the respective roost sites was not correlated with $\delta \mathrm{D}_{\mathrm{p}}$ values at each site (Bowen et al. 2005, Bowen 2009) $\left(\mathrm{D}_{\mathrm{f}}\right.$ adults $=$ $-64.108-1.3213{ }^{*} \mathrm{D}_{\mathrm{p},} F_{1,3}=2.51, P=0.21$ ) (Table 2).

Predicting $\delta \mathrm{D}_{\mathrm{p}}$ values for sites where juveniles fledged was more difficult because we did not know their origins. Also, the Palaearctic distribution of Amur Falcons is poorly documented, with breeding recorded as far south as Bhutan (see Figure 2; Baker 1935 in Feijen and Feijen 2008). The mean value for juvenile feathers $\left(\delta \mathrm{D}_{\mathrm{f}}\right)$ was $-58.8 \%$ which was well within expected values throughout the range of Amur Falcons in the Palaearctic (Figure 2; OIPC, Bowen 2009). Juvenile $\delta \mathrm{D}_{\mathrm{f}}$ values ranged from -83.9 to $-25.7 \%$. We predicted $\delta \mathrm{D}_{\mathrm{p}}$ values within the range of Palaearctic Amur Falcons to range from $-80.1 \%$ to $-46.1 \%$ (Figure 2; Table 3; Hobson et al. 2009). We therefore overlaid the range of $\delta \mathrm{D}_{\mathrm{p}}$ values from $-85 \%$ to $-40 \%$ to indicate the regions, within their known range, from where juvenile Amur Falcons originated (Figure 2; Table 3).

\section{Discussion}

\section{The Eastern Palaearctic to South Africa}

Because juvenile flight feathers of birds sampled in South Africa were grown on the nest in the Palaearctic, they were expected to represent the breeding origin of birds (Hobson and Wassenaar 1997, Meehan et al. 2001, Wassenaar and Hobson 2001, Hobson et al. 2004b). Most stable isotope studies on raptor species show a depletion in $\delta \mathrm{D}$ of feathers from precipitation of $37-$ $52 \%$ (Lott et al. 2003, Meehan et al. 2003). To predict the region where feathers of juveniles were grown we used a calibration curve determined for American Kestrels Falco sparverius that accounted for fractionation of $D$ from local annual precipitation to feathers (Hobson et al. 2009). We recorded a wide range $(-83.9$ to $-25.7 \%$ of feather $\delta \mathrm{D}$ values of juveniles with all predicted values for juveniles falling well within the range of expected annual $\delta \mathrm{D}_{\mathrm{p}}$ values of their Palaearctic distribution range. Not surprisingly, the northern limit of where juveniles were predicted to have originated (i.e. predicted northern limit of breeding range for birds sampled in

Table 2. Mean $(\% \pm \mathrm{SE}, \mathrm{AIR}) \delta^{15} \mathrm{~N}$ values of adult and juvenile feathers for different roost sites in South Africa, mean predicted $\delta \mathrm{D}$ values $(\% \pm \mathrm{SE}$, VSMOW) for precipitation during the moult period (DecemberFebruary) of Amur Falcons at different feather collection sites and mean $\delta \mathrm{D}$ values (\% $\pm \mathrm{SE}$, VSMOW) of feathers collected at respective sites during December 2008 - March 2009. Sample size in parentheses.

\begin{tabular}{llllll}
\hline \multirow{2}{*}{ Site } & \multicolumn{2}{l}{$\delta^{15} \mathrm{~N}$} & & $\delta \mathrm{D}$ & \\
\cline { 2 - 3 } \cline { 5 - 6 } & Adult & Juvenile & & Precipitation & Adult \\
\hline Naboomspruit & $7.8 \pm 0.8(10)$ & $7.2 \pm 0.4(4)$ & & $-22.0 \pm 1.2$ & $-40.4 \pm 4.0(10)$ \\
Middelburg & $6.9 \pm 0.7(10)$ & $6.2 \pm 0.9(7)$ & & $-28.0 \pm 1.2$ & $-31.0 \pm 4.9(10)$ \\
Ventersdorp & $8.3 \pm 0.5(10)$ & $8.2 \pm 0.7(10)$ & & $-25.0 \pm 1.2$ & $-37.2 \pm 5.1(10)$ \\
Heidelberg & $7.2 \pm 0.8(13)$ & $6.1(1)$ & & $-27.0 \pm 1.2$ & $-37.2 \pm 1.9(13)$ \\
Newcastle & $7.4 \pm 0.9(10)$ & $7.5 \pm 0.8(11)$ & & $-25.3 \pm 1.2$ & $-41.2 \pm 4.5(10)$ \\
Graaff-Reinet & - & $6.6 \pm 1.1(3)$ & & $-21.7 \pm 0.7$ & - \\
Pearston & $9.7(1)$ & - & & $-22.3 \pm 0.3$ & - \\
Mean & $7.6 \pm 0.3(54)$ & $7.3 \pm 0.4(36)$ & & $-25.0 \pm 2.7$ & $-37.4 \pm 1.8(53)$ \\
\hline
\end{tabular}




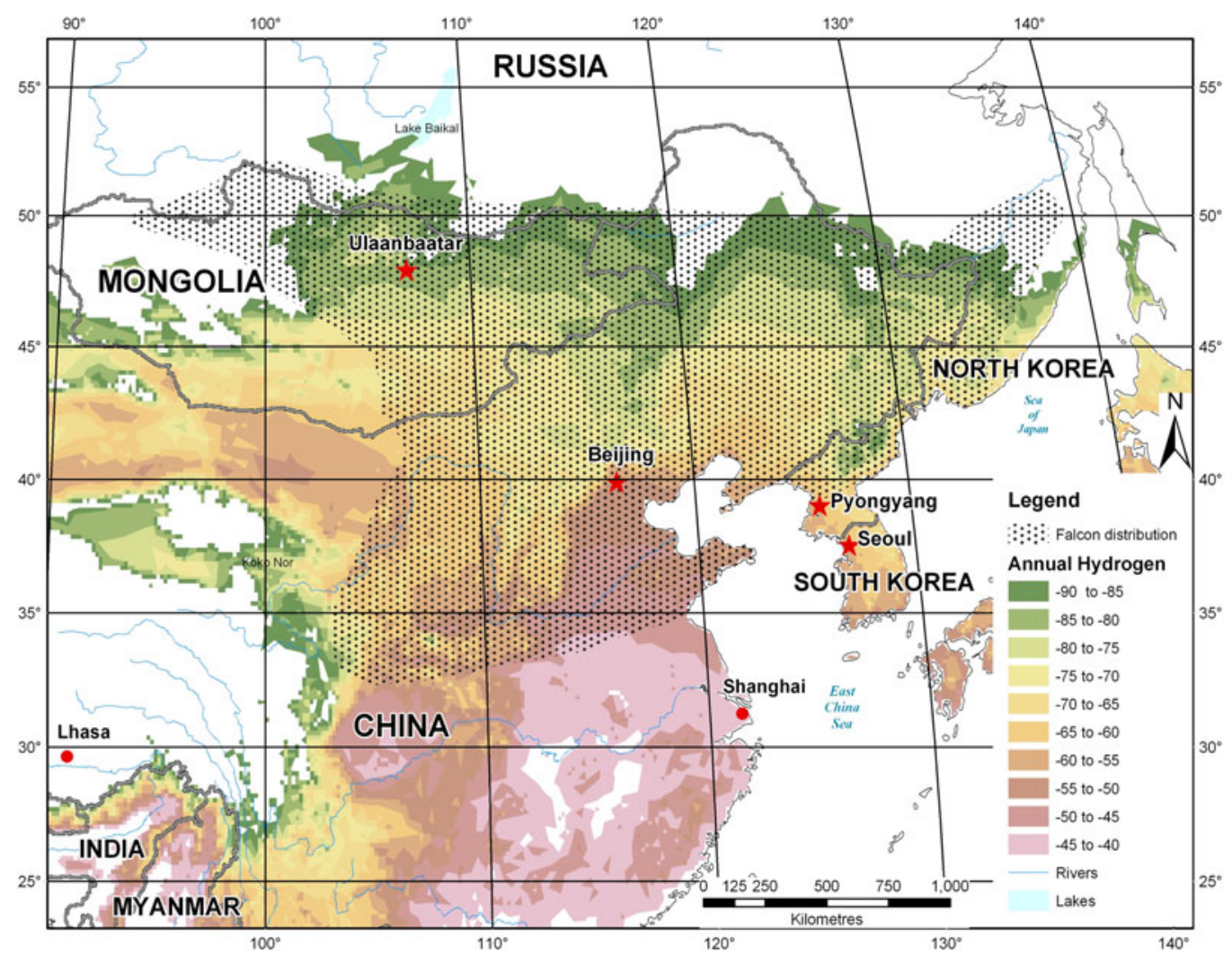

0
-1
5
5
0
0
3
5
0
0
2
0
2
0
5
0

Figure 2. Distribution of Amur Falcon Falco amurensis in the eastern Palaearctic during the boreal summer (modified from Moreau 1972, FergusonLees and Christie 2001, S. Gombobaatar unpubl. data), and regions within the range ( $\delta \mathrm{D}$ of precipitation, Bowen et al. 2005, Bowen 2009) that correspond to likely $\delta \mathrm{D}_{\mathrm{f}}$ values of juvenile Amur Falcons sampled in South Africa (Hobson et al. 2009; see Table 3). The isotopic range of $\delta \mathrm{D}_{\mathrm{p}}$, from where the birds are likely to have originated was determined using a calibration curve for American Kestrels Falco sparverius (Hobson et al. 20o9). Missing $\delta \mathrm{D}$ plots on the map do not fit within this range of predicted values, and become more depleted with an increase in latitude north. 
Table 3. Minimum, maximum and mean values ( \pm SE) (\%o, VSMOW) for juvenile feathers collected in South Africa with predicted $\delta \mathrm{D}$ values (\%o, VSMOW) of precipitation in Northern Hemisphere where feathers are likely to have grown. Predicted precipitation values calculated using calibration curve for American Kestrels $\left(\delta \mathrm{D}_{\mathrm{f}}=53.06+1.71^{*} \delta \mathrm{D}_{\mathrm{p}}, n=41\right.$; Hobson et al. 2009).

\begin{tabular}{|c|c|c|c|c|c|c|c|}
\hline \multirow[t]{2}{*}{ Site } & \multicolumn{3}{|c|}{ Feather } & \multicolumn{4}{|c|}{ Precipitation } \\
\hline & Min & Max & Mean & Min & Max & Mean & $n$ \\
\hline Naboomspruit & -55.5 & -35.2 & -46.5 & -51.6 & $-63 \cdot 5$ & -58.2 & 4 \\
\hline Middelburg & -78.4 & $-44 \cdot 5$ & -62.5 & -57.1 & -76.9 & -67.6 & 6 \\
\hline Ventersdorp & -72.6 & -32.8 & -62.2 & -50.2 & -73.5 & $-67 \cdot 4$ & 10 \\
\hline Heidelberg & - & - & $-63 \cdot 7$ & - & -68.3 & -68.3 & I \\
\hline Newcastle & -83.9 & $-25 \cdot 7$ & $-54 \cdot 3$ & -46.1 & -80.1 & -62.8 & 11 \\
\hline Graaff-Reinet & -71.3 & -48.2 & -63.6 & -59.2 & -72.7 & -68.2 & 3 \\
\hline Mean & -72.3 & -58.1 & -58.8 & -46.1 & -80.1 & -65.0 & 35 \\
\hline
\end{tabular}

South Africa) correlates well with the known northern limit of the distribution of Amur Falcons in the Palaearctic. Rather than attempting to pinpoint the origins of individual birds, we focused on assigning the origins of juveniles to a broad geographic band within the known range of breeding Amur Falcons (Langin et al. 2007). Our findings therefore suggest that juveniles in South Africa originated from throughout their distributional range in the Palaearctic (Figure 2, Wassenaar and Hobson 2001, Bowen and Revenaugh 2003, Hobson and Wassenaar 2008). However, birds from a region west of Ulaanbaatar, Mongolia, appear not to have been sampled. This may reflect an absence of birds from this region in South Africa or simply inconsistencies in our method of analysis. Amur Falcons have been recorded breeding north of Ulaanbaatar and 378 individuals have been ringed in a study there (Schäfer and Stubbe 2005). However, none of these individuals have been recovered in their "overwintering" grounds. This is more likely a reflection of the low numbers of recoveries and difficulties in catching birds in their overwintering range.

Because there is temporal variation in the $\delta \mathrm{D}$ values of precipitation we cannot be sure that hydrogen contributions to feather growth reflected values for an entire annual period, rather than $\delta \mathrm{D}$ values of precipitation for June, the month in which juveniles grew tail feathers (Schäfer 2005). However, we consider the former scenario more likely because prey of Amur Falcons will probably reflect the signature of prey that had assimilated resources representing a broader time period prior to feather growth. It is, however, interesting to note that when precipitation values in the breeding range are considered for June, the origins of juveniles sampled in South Africa extends further north than their known distribution in the Palaearctic. Although plausible, this seems less likely.

On global and regional scales the distribution of $\mathrm{C}_{3}$ and $\mathrm{C}_{4}$ grasses has been well documented with $\mathrm{C}_{4}$ grasses largely restricted to warmer climates and (lower latitudes and altitudes) (e.g. Teeri and Stowe 1976, Stowe and Teeri 1978, Vogel et al. 1978, Hattersley 1983). Also, there is a general decrease in the proportion of $\mathrm{C}_{4}$ grasses with an increase in latitude (cooler climates). We therefore expected enriched (more positive) $\delta^{13} \mathrm{C}$ values, representing carbon input from a $\mathrm{C}_{3}$ dominated system, to reflect a more northerly origin for juveniles (Kelly et al. 2002). For juveniles sampled in South Africa there was a general trend of northern-most birds representing a stronger $C_{4}$ dietary signature, and more southerly populations having a stronger $C_{3}$ signature. In the northern hemisphere the diet of juveniles includes a greater proportion of mammals, birds and amphibians (Schäfer 2003, Pietersen and Symes 2010) so the link between $\delta^{13} \mathrm{C}$ values and latitude is less plausible for inferring breeding origins of South African birds. A more adequate explanation is that the wide range of $\delta^{13} \mathrm{C}$ values represents the variable ingestion of prey items from $\mathrm{C}_{3}$ and $\mathrm{C}_{4}$ sources.

Carbon input from the environment may therefore not be a good indicator of latitudinal origin because of diet switching between $\mathrm{C}_{3}$ and $\mathrm{C}_{4}$ resources at a site, or the broad spatial use of resources by adults feeding nestlings. This pattern is also reflected in the wide range of $\delta^{13} \mathrm{C}$ 
values of adult feathers in South Africa suggesting that birds within a roost are not all relying on the same food source, or food type, and that they are sourcing their diet from both $\mathrm{C}_{3}$ and $\mathrm{C}_{4}$ systems. Carbon sourced from both $\mathrm{C}_{3}$ and $\mathrm{C}_{4}$ in different adult individuals from the same roost may thus reflect, i) a wide feeding niche with reliance on $\mathrm{C}_{3}$ (strong broadleaved or high altitude and/or altitude grassland influence) to $\mathrm{C}_{4}$ (low altitude and/or altitude grassland) and/or crops (e.g. maize), and/or, ii) the sampling of birds whose feathers had grown with resources beyond that reflected in the vicinity of the roost. This latter point is supported by the lack of a positive correlation between the $\delta \mathrm{D}_{\mathrm{f}}$ values of adult feathers and the mean $\delta \mathrm{D}_{\mathrm{p}}$ of precipitation at the sites where feathers were collected, i.e. sites where feathers were presumed to have moulted if adult Amur Falcons were faithful to roost sites.

\section{Roosting in colonies}

The 2009 National Kestrel Count Day (24 January) recorded 111,291 Amur Falcons at 32 roosts in South Africa (www.kestreling.com). This annual national count has, over the past five years recorded significant changes in roost sizes, with some roosts being abandoned (www.kestreling.com). Also, it represents only a fraction of the estimated global population of 100,000-1,000,000 birds (Global Raptor Information Network 2008, BirdLife International 2008). Usually roosts are active over several consecutive years, although numbers within each roost are known to vary within and between seasons (www.kestreling.com). These changes may reflect a movement of birds across the subregion and real changes in Amur Falcon numbers at regularly counted roost sites. In addition they may reflect an absence of birds in the subregion, adding support to the idea that a large proportion of birds do not reach South Africa to overwinter. The proportion of the population not reaching South Africa may overwinter further north and we suggest that it comprises birds starting their migration later (Figure 2). These birds probably overwinter in Namibia, Zambia, Zimbabwe, Malawi and Mozambique, with some birds remaining as far north as Tanzania (Mendelsohn 1997, Stevenson and Fanshawe 2002, Jenkins 2005). Other overwintering sites remain to be investigated and could likely include the Indian sub-continent (Mendelsohn 1997, Jenkins 2005).

The $\delta \mathrm{D}$ values of adult feathers, as predicted, were more depleted relative to predicted $\delta \mathrm{D}$ values in precipitation. Adults undergo a near complete moult in South Africa (Schäfer 2003) so we expected feathers to represent the site at which they were collected (see Hobson and Wassenaar 2008). There was no correlation of $\delta \mathrm{D}_{\mathrm{f}}$ values with $\delta \mathrm{D}_{\mathrm{p}}$ suggesting that feathers grown in South Africa did not grow at the roost site where they were collected (OIPC, Bowen 2009). It is unknown whether roost site fidelity is high within a season, or whether the same birds return to the same roost site each year. Given these data, and large variation in roost counts between years, we suggest that roost site fidelity is low, with a prolific movement of birds across the southern African subregion both within and between years. Because individual birds are not fixed to a specific site by breeding they are able to wander, feeding on the episodic and patchy occurrence of food resources such as crop pests (e.g. maize pests), and grasshopper and termite alate irruptions (Brown 1971, Brown et al. 1982, Pietersen and Symes 2010).

Most grasses within the range of Amur Falcon in South Africa are $\mathrm{C}_{4}$ although the diet of falcons is not confined to arthropods reliant on this vegetation type (Vogel et al. 1978, Mendelsohn 1979, 1997, Jenkins 2005, Pietersen and Symes 2010). If all adult Amur Falcons at a roost site were feeding on a similar diet during the period of feather growth in South Africa we would expect them to have similar carbon isotope values in feathers. This was not the case and diet studies indicate they feed on wide range of invertebrates (Mendelsohn 1979, 1997, Jenkins 2005, Kopij in press, Pietersen and Symes 2010). The wide range of $\delta^{13} \mathrm{C}$ values is therefore associated with a variable diet and foraging over a wide area to access these food sources.

Rectrices were used because they can be readily aged and sexed and are freely available below roosts as part of the normal moult process. However, they may not be the best feathers for isotope studies because they are much more likely to be dropped and replaced irregularly and not as part 
of the normal physiological moult processes e.g. during escape from predation. The wide range of samples (and outliers) for adults and juveniles may therefore be the result of irregular moult patterns and not identification error. Remiges may have yielded better results but with the current sampling method, ageing and sexing of remiges would not have been possible.

\section{Trophic position}

In the open savanna environment where Amur Falcons were recorded, the $\delta^{15} \mathrm{~N}$ values of invertebrates found in the grass $\left(\mathrm{C}_{4}\right)$ and wooded vegetation $\left(\mathrm{C}_{3}\right)$ over five months were sampled and mean values $( \pm \mathrm{SD})$ of $4.7 \pm 1.4 \%$ and $6.3 \pm 1.9 \%$ recorded respectively $(n=15$ each) (Symes et al. unpubl. data). This suggests that the values for adults $(7.6 \pm 0.3 \%$ ) are in line with a typical open savanna/grassland invertebrate diet, being an estimated one tropic position above the invertebrates in this system. Values of juveniles and adults were similar suggesting that in South Africa and the Palaearctic Amur Falcons feed at a similar trophic level in both regions. In South Africa the diet of Amur Falcons has been shown to include solifugids, beetles, termites but seldom rodents and birds (Mendelsohn 1997, Jenkins 2005, Kopij in press, Pietersen and Symes 2010). However, dietary information on juveniles suggests otherwise; mammals, birds and amphibians appear to be more important dietary items for nestlings (Schäfer 2003). En route diets are not known and difficult to interpret from stable isotope analysis and it is unknown whether Amur Falcons rely on stop-over feeding sites during migration. Their migration patterns may be timed to take advantage of prevailing weather conditions, moving ahead of the ITCZ with the shifting of seasons, much the same as dragonfly migrations between Africa and India (Anderson 2009). During the non-breeding period of Amur Falcons in South Africa, the irruption of termite alate and crop-pest species, important food sources, may often be unpredictable and patchy; in the Palaearctic this may be less so, although a wide range of $\delta^{15} \mathrm{~N}$ values suggests a nitrogen input from a range of trophic levels for both adults in South Africa and juveniles in the Palaearctic.

\section{Conclusions}

The status of the Amur Falcon is currently unclear and there is little evidence for recent changes in its distribution and numbers in Africa (Mendelsohn 1997, Global Raptor Information Network 2008, BirdLife International 2008). In light of recent findings that the total number of birds recorded in South Africa alone is significantly below that estimated for the total world population, either a significant proportion of the population overwinter north of South Africa or the global estimate is significantly over-inflated (Global Raptor Information Network 2008, BirdLife International 2008, A. van Zyl pers. comm.). The grassland regions within their South African range, upon which they are reliant for foraging, is under threat from agriculture, afforestation and open-cast mining (Mendelsohn 1997, Jenkins 2005). Stomach content analysis suggests that Amur falcons forage successfully over maize monoculture (Pietersen and Symes 2010) indicating some flexible adaptation to anthropogenic changes. Also, the isotopic evidence suggests that the niche occupied by the Amur Falcons during their stay in South Africa is cosmopolitan, with a broad dietary base and opportunistic exploitation of wide spatial ranges. Before the conservation status of the species can be concluded, the niche bottlenecks associated with migration and breeding at other locations on their annual migration also need to be considered. For example reports of large scale capture of migrating birds at important stopover sites in northern India are cause for concern (Tan 2009). In the northern hemisphere, the picture is less clear, and although the entire population may disperse over a breeding range far greater $\left(\sim 4,000,000 \mathrm{~km}^{2}\right)$ than the South African range $\left(\sim 500,000 \mathrm{~km}^{2}\right)$, similar factors may affect its conservation there. The species is categorised globally as a species of "Least Concern" by BirdLife International (2008). With rapid changes in human population growth and the associated impacts on the environment, more information is required to ensure the long term persistence of this long-distance migratory raptor. 


\section{Acknowledgements}

The University of the Witwatersrand are thanked for providing funding for this project. Zephné Bernitz is thanked for assisting in age and sex identification of feathers, and for collecting feather samples from the Middelburg roost. Shirley Grindley and Roy Stauth (Graaff-Reinet), Saartjie Kidson (Naboomspruit), Rina Pretorius (Newcastle) and Ria Martins (Heidelberg) are thanked for collecting feather samples. Tamar Cassidy is thanked for access to skins in the Transvaal Museum (Pretoria), and the Northern Flagship Institution is thanked for permission to sample Amur Falcon feathers in the Transvaal Museum collection and for access to moult data. Dr. Sundev Gombobaatar (Gomboo) (National University of Mongolia) is also thanked for additional comments and providing Amur Falcon distribution maps. Tracy Symes and Jolene Fischer are thanked for assistance in map construction. Anthony van Zyl, Zephné Bernitz and an anonymous reviewer are thanked for comments to help improve the quality of the manuscript.

\section{References}

Alerstam, T. (1990) Bird migration. Cambridge, UK: Cambridge University Press.

Ali, S. and Ripley, S. D. (1987) Handbook of the birds of India and Pakistan. Compact (2nd) edition. Delhi: Oxford University Press.

Anderson, R. C. (2009) Do dragonflies migrate across the western Indian Ocean? J. Tropical Ecol. 25: 347-358.

Baker, E. C. S. (1935) The nidification of birds of the Indian Empire, Vol. IV. London: Taylor and Francis.

Benson, C. W. (1951) A roosting site of the Eastern Red-footed Falcon, Falco amurensis. Ibis 93: 467-468.

Bernitz, Z. (2006) Mass die-off of migrating kestrels: Ventersdorp. Gabar 17: 2-4.

Bildstein, K. L. and Zalles, J. I. (2005) Old World versus New World long-distance migration in accipiters, buteos and falcons: the interplay of migration ability and global biogeography. Pp. $154-167$ in R. Greenberg and P. P. Marra, eds. Birds of two worlds: the ecology and evolution of migration. Baltimore: Johns Hopkins University Press.

Bildstein, K. L., Zalles, J., Ottinger, J. and McCarty, K. (2000) Conservation biology of the world's migratory raptors: status and strategies. Pp. 573-590 in R. D. Chancellor and B-U. Meyburg, eds. Raptors at risk. Surrey, BC, Canada: Hancock House and World Working Group on Birds of Prey.

BirdLife International (2008) Species factsheet: Falco amurensis. Downloaded from http:// www.birdlife.org on 19 December 2008.
Bowen, G. J. (2009) The Online Isotopes in Precipitation Calculator, version 2.2 . Downloaded from http://www.waterisotopes.org on 16 November 2009

Bowen, G. J. and Revenaugh, J. (2003) Interpolating the isotopic composition of modern meteoric precipitation. Water Resour. Res. 39: 1299, doi:10.129/2003 WRoo2086.

Bowen, G. J., Wassenaar, L. I. and Hobson, K. A. (2005) Global application of stable hydrogen and oxygen isotopes to wildlife forensics. Oecologia 143: 337-348.

Brown, L. (1971) African birds of prey. Boston, Mass: Houghton Mifflin.

Brown, L. H., Urban, E. K. and Newman, K. (1982) The birds of Africa, Vol. 1. London, UK: Academic Press.

Cade, T. J. (1982) Falcons of the world. Ithaca, NY: Cornell University Press.

Cerling, T. E., Wittemyer, G., Rasmussen, H. B., Vollrath, F., Cerling, C. E., Robinson, T. J. and Douglas-Hamilton, I. (2006) Stable isotopes in elephant hair document migration patterns and diet changes. PNAS 103: $371-373$.

Chamberlain, C. P., Bensch, S., Feng, X., Åkesson, S. and Andersson, T. (2000) Stable isotopes examined across a migratory divide in Scandinavian willow warblers (Phylloscopus trochilus trochilus and Phylloscopus trochilus acredula) reflect their African winter quarters. Proc. R. Soc. London B 267: 43-48.

Chamberlain, C. P., Blum, J. D., Holmes, R. T., Feng, X., Sherry, T. W. and Graves, G. R. 
(1997) The use of isotope tracers for identifying populations of migratory birds. Oecologia 109: 132-141.

Cheng, T-h. (1987) A synopsis of the avifauna of China. Beijing: Science Press.

Dawson, T. E., Mambelli, S., Plamboeck, A. H., Templer, P. H. and Tu, K. P. (2002) Stable isotopes in plant ecology. Annu. Rev. Ecol. Syst. 33: 507-559.

Dingle, H. (2008) Bird migration in the southern hemisphere: a review comparing continents. Emu 108: 341-359.

Ehleringer, J. R. (1991) ${ }^{13} \mathrm{C} /{ }^{12} \mathrm{C}$ fractionation and its utility in terrestrial plant studies. Pp. $1-16$ in P. W. Rundel., J. R. Rundel and K. A. Nagy, eds. Stable isotopes in ecological research. New York: Springer-Verlag.

Feijen, C. and Feijen, H. R. (2008) A review of the breeding birds of Bhutan. Forktail 24: 1-24.

Ferguson-Lees, J. and Christie, D. A. (2001) Raptors of the world. London: Christopher Helm.

Global Raptor Information Network (2008) Species account: Amur Falcon Falco amurensis. Downloaded from http://www. globalraptors.org on 19 December 2008.

Hattersley, P. W. (1983) The distribution of $\mathrm{C}_{3}$ and $\mathrm{C}_{4}$ grasses in Australia in relation to climate. Oecologia 57: 113-128.

Hobson, K. A. and Wassenaar, L. I. (1997) Linking breeding and wintering grounds of neotropical songbirds using stable hydrogen isotopic analysis of feathers. Oecologia 109: 142-148.

Hobson, K. A. (2008) Using endogenous and exogenous markers in bird conservation. Bird Conserv. Internatn 18 (Suppl. 1): Si74-Sig9.

Hobson, K. A. and Wassenaar, L. I. (1999) Stable isotope ecology: an introduction. Oecologia 120: 312-313.

Hobson, K. A. and Wassenaar, L. I. (2008) Tracking animal migration with stable isotopes. Amsterdam, The Netherlands: Elsevier.

Hobson, K. A., Aubry, Y. and Wassenaar, L. I. (2004a) Migratory connectivity in Bicknell's thrush: locating missing populations with hydrogen isotopes. Condor 106: 905-909.

Hobson, K. A., Bowen, G. J., Wassenaar, L. I., Ferrand, Y. and Lormee, H. (2004b) Using stable hydrogen and oxygen isotope measurements of feathers to infer geographical origins of migrating European birds. Oecologia 141: 477-488.

Hobson, K. A., deMent, S. H., Van Wilgenburg, S. L. and Wassenaar, L. I. (2009) Origins of American Kestrels wintering at two southern U.S. sites: An investigation using stable-isotope $\left(\delta \mathrm{D}, \delta^{18} \mathrm{O}\right)$ methods. J. Raptor Res. 43: 325-337.

Hobson, K. A., Wassenaar, L. I., Milá, B., Lovette, I., Dingle, C. and Smith, T. B. (2003) Stable isotopes as indicators of altitudinal distributions and movements in an Ecuadorean hummingbird community. Oecologia 136: 302-308.

Jenkins, A. R. (2005) Amur Falcon Falco amurensis. Pp. 552-553 in P. A. R. Hockey, W. R. J. Dean and P. G. Ryan, eds. Roberts' birds of southern Africa. $7^{\text {th }}$ edn. Cape Town, South Africa: Trustees of the John Voelcker Bird Book Fund.

Kelly, J. F. (2000) Stable isotopes of carbon and nitrogen in the study of avian and mammalian trophic ecology. Can. J. Zool. 78: $1-27$.

Kelly, J. F., Atudorei, V., Sharp, Z. D. and Finch, D. M. (2002) Insights into Wilson's Warbler migration from analyses of hydrogen stable-isotope ratios. Oecologia 130: 216-221.

Kjellen, N., Hake, M. and Alerstam, T. (1997) Strategies of two ospreys Pandion haliaetus migrating between Sweden and tropical Africa as revealed by satellite tracking. J. Avian Biol. 28: 15-23.

Kopij, G. (in press) Seasonal variation in the diet of the Amur kestrel (Falco amurensis) in its winter quarter in Lesotho. Af. J. Ecol. doi 10.1111/j.1365-2028.2009.01130.x.

Langin, K. M., Reudink, M. W., Marra, P., Norris, D. R., Kyser, T. K. and Ratcliffe, L. M. (2007) Hydrogen isotope variation in migratory bird tissues of known origin: implications for geographic assignment. Oecologia 152: 449-457.

Lott, C. A. and Smith, J. P. (2006) A geographic-information-system approach to estimating the origin of migratory raptors in North America using hydrogen stable isotope ratios in feathers. Auk 123: 822835 . 
Lott, C. A., Meehan, T. D. and Heath, J. A. (2003) Estimating the latitudinal origins of migratory birds using hydrogen and sulfur stable isotopes in feathers: influence of marine prey base. Oecologia 134: 505510.

McClure, H. E. (1998) Migration and survival of the birds of Asia. Bangkok, Thailand: White Lotus Press.

Meehan, T. D., Lott, C. A., Sharp, Z. D., Smith, R. B., Rosenfield, R. N., Stewart, A. C. and Murphy, R. K. (2001) Using hydrogen isotope geochemistry to estimate the natal latitudes of immature Cooper's Hawks migrating through the Florida Keys. Condor 103: 11-20.

Meehan, T. D., Rosenfield, R. N., Atudore, V. N., Bielefeldt, J., Rosenfield, L. J., Stewart, A. C., Stout, W. E. and Bozek, M. A. (2003) Variation in hydrogen stable-isotope ratios between adult and nestling Cooper's Hawks. Condor 105: 567-572.

Mendelsohn, J. M. (1979) A note on hunting in Lesser and Eastern Redfooted Kestrels. Ostrich 50: 121-122.

Mendelsohn, J. M. (1997) Eastern Redfooted Kestrel Falco amurensis. Pp. 262-263 in J. A. Harrison, D. G. Allan, L. G. Underhill, M. Herremans, A. J. Tree, V. Parker and C. J. Brown, eds. The atlas of South African birds. Volume 1: Non-passerines. Johannesburg, South Africa: BirdLife South Africa.

Meyburg, B.-U., Ellis, D. H., Meyburg, C., Mendelsohn, J. M. and Scheller, W. (2001) Satellite tracking of two Lesser Spotted Eagles, Aquila pomarina, migrating from Namibia. Ostrich 72: 35-40.

Meyburg, B.-U., Mendelsohn, J. M., Ellis, D. H., Smith, D. G., Meyburg, C. and Kemp, A. C. (1995) Year-round movements of a Wahlberg's Eagle Aquila wahlbergi tracked by satellite. Ostrich 66: 135-140.

Minagawa, M. and Wada, E. (1984) Stepwise enrichment of ${ }^{15} \mathrm{~N}$ along food chains: further evidence and the relation between $\delta^{15} \mathrm{~N}$ and animal age. Geochim. Cosmochim. Acta 48: 1135-1140.

Mizutani, H., Fukuda, M. and Kabaya, Y. (1992) ${ }^{13} \mathrm{C}$ and ${ }^{15} \mathrm{~N}$ enrichment factors of feathers of 11 species of adult birds. Ecology 73: 1391-1395.
Moreau, R. E. (1972) The Palaearctic-African bird migration systems. London and $\mathrm{New}$ York: Academic Press.

Newton, I. (1995) Relationship between breeding and wintering ranges in Palaearctic-African migrants. Ibis 137: 241-249.

Orta, J. (1994) Amur Falcon. Pp. 265-266 in J. del Hoyo, A. Elliott and J. Sargatal, eds. Handbook of birds of the world. Vol. 2. New World vultures to guineafowl. Barcelona, Spain: Lynx Edicions.

Park, R. and Epstein, S. (1960) Carbon isotope fractionation during photosynthesis. Geochim. Cosmochim. Acta 21: 11.

Park, R. and Epstein, S. (1961) Metabolic fractionation of ${ }^{13} \mathrm{C}$ and ${ }^{12} \mathrm{C}$ in plants. Plant Physiol. 36: 133-138.

Peterson, B. J. and Fry, B. (1987) Stable isotopes in ecosystem studies. Annu.Rev. Ecol. Sys. 18: 293-320.

Pietersen, D. W. and Symes, C. T. (2010) Assessing the diet of Amur Falcon Falco amurensis and Lesser Kestrel Falco naumanni using stomach content analysis. Ostrich 81: 39-44.

Post, D. M. (2002) Using stable isotopes to estimate trophic position: models, methods, and assumptions. Ecology 83: 703-718.

Sanderson, F. J., Donald, P. F., Pain, D. J., Burfield, I. J. and van Bommel, F. P. J. (2006) Long-term population declines in Afro-Palearctic migrant birds. Biol. Conserv. 131: 93-105.

Schäfer, S. (2003) Studie an einer mongolischen Brutpopulation des Amurfalken (Falco amurensis Radde, 1863). Unpublished Dipl. Biol. thesis. Halle/Saale, Germany: Martin-Luther Universität Halle-Wittenberg.

Schäfer, S., and Stubbe, M. (2005) Brutökologische Untersuchungen am Amurfalken Falco amurensis in der nördlichen Mongolei (thesis abstract). Vogelwarte: Z. Vogelkunde 43: 61-96.

Smith, B. N. and Epstein, S. (1971) Two categories of ${ }^{13} \mathrm{C}^{12} \mathrm{C}$ ratios for higher plants. Plant Physiol. 47: 380-384.

Stowe, L. G. and Teeri, J. A. (1978) The geographic distribution of $\mathrm{C}_{4}$ species of the Dicotyledonae in relation to climate. Am. Nat. 112: 609-623. 
Strandberg, R., Klaassen, R. H. G., Hake, M., Olofsson, P. and Alerstam, T. (2009) Converging migration routes of Eurasian hobbies Falco subbuteo crossing the African equatorial rain forest. Proc. R. Soc. B 276: 727-733.

Stevenson, T. and Fanshawe, J. (2002) Birds of East Africa: Kenya, Tanzania, Uganda, Rwanda, Burundi. London: T \& AD Poyser Ltd.

Tan, J. S. Y. (2009) A sad encounter with migratory Amur Falcons in Nagaland. Downloaded from http://besgroup.talfrynature. com/2009/11/25/a-sad-encounter-withmigratory-amur-falcons-in-nagaland/ on 30 November 2009.

Tarboton, W. and Allan, D. (1984) The status and conservation of birds of prey in the Transvaal. Pretoria: Transvaal $\mathrm{Mu}-$ seum. (Transvaal Museum Monograph. vol. 3).

Teeri, J. A. and Stowe, L. G. (1976) Climatic patterns and distribution of $\mathrm{C}_{4}$ grasses in North America. Oecologia 23: 1-12.

Trierweiler, C., Koks, B. J., Drent, R. H., Exo, K.-M., Komdeur, J., Dijkstra, C. and Bairlein, F. (2007) Satellite tracking of two Montagu's Harriers (Circus pygargus): dual pathways during autumn migration. J. Ornith. 148: 513-516.
Vogel, J. C., Fuls, A. and Ellis, R. P. (1978) The geographical distribution of Kranz grasses in South Africa. S. Afr. J. Sci. 74: 209-215.

Wakelin, J., McKechnie, A. E. and Woodborne, S. M. In press. Stable isotope analysis of migratory connections in a threatened intraAfrican migrant, the Blue Swallow (Hirundo atrocaerulea). J. Ornith.

Wassenaar, L. I. and Hobson, K. A. (2001) A stable-isotope approach to delineate geographical catchment areas of avian migration monitoring stations in north America. Environ. Sci. Technol. 35: 1845-1850.

Wassenaar, L. I. and Hobson, K. A. (2003) Comparative equilibration and online technique for determination of non-exchangeable hydrogen of keratins for use in animal migration studies. Isot. Environ. Health Stud. 39: 211-217.

Yohannes, E., Hobson, K. A. and Pearson, D. J. (2007) Feather stable-isotope profiles reveal stopover habitat selection and site fidelity in nine migratory species moving through sub-Saharan Africa. J. Avian Biol. 38: $347-355$.

Yohannes, E., Hobson, K. A., Pearson, D. J. and Wassenaar, L. I. (2005) Stable isotope analyses of feathers help identify autumn stop-over sites of three long-distance migrants in northeastern Africa. J. Avian Biol. 36: 235-241.

\section{CRAIG T. SYMES*}

School of Animal, Plant and Environmental Sciences, University of the Witwatersrand, Private Bag 3, Wits 2050, South Africa

\section{STEPHAN WOODBORNE}

School of Animal, Plant and Environmental Sciences, University of the Witwatersrand, Private Bag 3, Wits 2050, South Africa

Natural Resources and the Environment, CSIR, P.O. Box 395, Pretoria 0oo1, South Africa

${ }^{*}$ Author for correspondence; e-mail: craig.symes@wits.ac.za

Received 11 December 2009; revision accepted 5 March 2010; Published online 30 March 2010 
Appendix A. Specimen numbers of Amur Falcons from Ventersdorp sampled at the Transvaal Museum, Pretoria (Northern Flagship Institution).

\begin{tabular}{llll}
\hline No & Age & Sex & Code \\
\hline 1 & Adult & Male & TM78635 \\
2 & & & TM78686 \\
3 & & & TM78704 \\
4 & & & TM78717 \\
5 & & Female & TM78728 \\
6 & & & TM78718 \\
7 & & & TM78741 \\
8 & & & TM78854 \\
9 & & Male & TM78867 \\
10 & & & TM78869 \\
\hline 11 & Juvenile & & TM78639 \\
12 & & & TM78687 \\
13 & & Female & TM78699 \\
14 & & TM78716 \\
15 & & TM78871 \\
16 & & TM78684 \\
17 & & TM78706 \\
18 & & TM78709 \\
19 & & & TM78711 \\
20 & & & TM78723 \\
\hline
\end{tabular}

